Volume 7 Nomor 1 halaman $11-20$

eISSN: 2654-9735, pISSN: 2089-6026

\title{
Pra-Produksi Aplikasi Permainan Simulasi Budidaya Kolam Edukatif untuk Meningkatkan Minat Generasi Muda Terhadap Perikanan Budidaya
}

\section{Pre-Production of Educative Pond Cultivation Simulation Game to Increase the Interest of Young Generation Towards Aquaculture}

\author{
DADY DARMAWAN ${ }^{1}$, AUZI ASFARIAN $^{1 *}$, FAJAR MAULANA ${ }^{2}$
}

\begin{abstract}
Abstrak
Potensi sektor perikanan di Indonesia menjadi bagian penting dalam pembangunan nasional. Penelitian ini dilakukan untuk merancang aplikasi permainan edukatif berupa simulasi perikanan budidaya sehingga dapat memperkenalkan tentang perikanan budidaya kepada generasi muda melalui cara yang lebih menarik. Proses praproduksi yang dilaksanakan pada penelitian ini menghasilkan dokumen desain permainan yang dibuat berdasarkan wawancara dan studi literatur. Hasil dari penelitian ini telah berhasil menghasilkan rancangan aplikasi permainan yang edukatif dan sangat menarik. Dokumen tersebut memuat unsur-unsur permainan yang meliputi objek dan perilakunya yang akan digunakan untuk membuat permainan simulasi. Hasil penelitian ini diharapkan dapat menghasilkan rancangan aplikasi permainan yang dapat digunakan untuk menambah wawasan pemain tentang perikanan budidaya
\end{abstract}

Kata Kunci: edukatif, permainan, perikanan, perikanan budidaya, simulasi

\begin{abstract}
The potential of the fisheries sector in Indonesia is an essential part of national development. This research was conducted to design an educational game application in the form of aquaculture simulation so that it can introduce aquaculture to the younger generation through more exciting way. The pre-production process carried out in this study produced game design documents that were based on interviews and literature studies. This study has successfully create a game design documents of educational game to introduce aquaculture in an interesting way. The document contains elements of the game that include objects and behavior that will be used to create a simulation game. The results of this study are expected to produce a game application design that can be used to add insight into players about aquaculture.
\end{abstract}

Keywords: aquaculture, education game, fishery, game, simulation

\section{PENDAHULUAN}

Pertumbuhan perikanan budidaya menjadi bagian penting dalam penyediaan pasokan ikan untuk pangan nasional, regional, dan dunia (Phillips et al. 2016). Indonesia memiliki banyak wilayah laut dan terletak pada kondisi geopolitis yang strategis di antara lautan Pasifik dan lautan Hindia. Kondisi kelautan Indonesia yang strategis menjadikan sektor ini bagian penting dalam pembangunan nasional. Pengembangan usaha perikanan di Indonesia memiliki prospek yang sangat tinggi dan diperkirakan dapat dimanfaatkan untuk mendorong pertumbuhan ekonomi hingga 82 miliar dolar per tahun (SetKabRI 2016). Akan tetapi, minat generasi muda terhadap sektor ini masih perlu ditingkatkan.

\footnotetext{
${ }^{1}$ Departemen Ilmu Komputer, FMIPA, Institut Pertanian Bogor

${ }^{2}$ Departemen Budidaya Perairan, Fakultas Perikanan, Institut Pertanian Bogor

*Penulis Korespondensi: Tel/Faks: 0251-8625584; Surel: asfarian@apps.ipb.ac.id
} 
Aplikasi permainan dapat dimanfaatkan sebagai alat untuk menyampaikan hal-hal yang bersifat edukatif, membuat pemain berperan lebih aktif dalam proses pembelajaran melalui interaksi di permainan tersebut, serta memotivasi pemain (Vicuna 2017; Pho dan Dinscore 2015). Aplikasi permainan dapat menyampaikan informasi penting kepada pemain sehingga pemain dapat mengambil tindakan yang sesuai dengan keadaan saat ini. Akan tetapi, Haworth (2011) mengungkapkan bahwa banyak aplikasi permainan edukatif yang gagal mencapai tujuan akibat rancangan aplikasi permainan yang buruk.

Penelitian yang dilakukan oleh Vicuna (2017) mempelajari penggunaan aplikasi permainan sebagai media untuk mengajar dan untuk melihat bagaimana aplikasi permainan tersebut dapat menciptakan pengalaman menyenangkan bagi pemain sambil menjalankan fungsinya sebagai media penyampaian materi. Namun, hanya memasukkan materi edukatif ke dalam aplikasi permainan tidaklah cukup sehingga perlu dilakukan perancangan agar materi dapat disampaikan dengan menyenangkan. Permainan perlu dirancang, salah satunya dalam bentuk dokumen desain permainan (Stanley 2014), atau game design document (GDD), yang memuat rancangan dari berbagai aspek permainan seperti genre atau gaya (Clearwater 2011) dan mekanik permainan.

Penelitian ini dilakukan untuk merancang aplikasi permainan simulasi perikanan budidaya. Gaya simulasi dipilih karena dapat mengembangkan kemampuan pemain dengan menerapkan ilmu dan kemampuan yang ia peroleh sepanjang permainan (Andreu-Andréz dan García-Casas 2011). Penelitian ini menggunakan game development life cycle (Ramadan dan Widyani 2013) sebagai pedoman pengembangan serta menggunakan pendekatan-pendekatan hasil penelitian Vicuna (2017) dalam merancang aplikasi permainan edukatif yang efektif dan menarik. Hasil dari penelitian ini, yang berupa GDD, dapat dikembangkan menjadi aplikasi permainan yang dapat dimanfaatkan untuk membantu penyampaian informasi mengenai perikanan budidaya.

\section{METODE}

Penelitian ini menggunakan tahap inisiasi dan pra-produksi (Gambar 1) pada GDLC (Ramadan dan Widyani 2013) sebagai pedoman pengembangan. Tahapan terdiri atas insiasi, pembuatan GDD, pembuatan mock-up, atau contoh kasar, serta evaluasi yang pada penelitian ini dilakukan oleh pakar budidaya perairan.

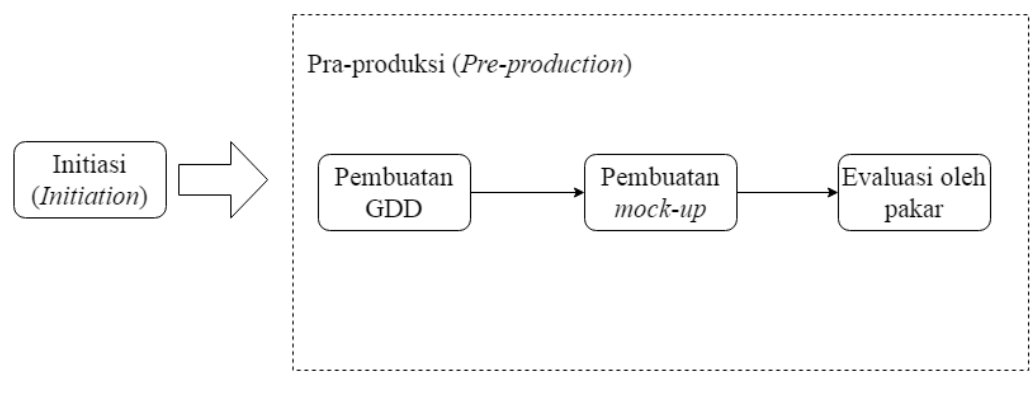

Gambar 1 Tahapan penelitian.

- Inisiasi: Pada tahap ini dilakukan wawancara dengan pakar perikanan budidaya dari Fakultas Perikanan, Institut Pertanian Bogor. Wawancara dilakukan di Kolam Percobaan Departemen Budidaya Perairan sekaligus untuk melakukan studi di lapangan. Studi literatur juga dilakukan untuk melengkapi informasi yang dibutuhkan untuk membuat GDD menggunakan Standar Nasional Indonesia (SNI) sebagai sumber informasi.

- Pembuatan Dokumen Perancangan Permainan: Hasil dari tahap inisiasi kemudian diterjemahkan menjadi elemen pada GDD yang terdiri atas gaya permainan, mekanik permainan, rancangan monetisasi, karya yang berpengaruh pada rancangan, lingkup 
pengembangan, dan faktor edukasi. Pembuatan GDD dilakukan dengan menganalisis hasil pengumpulan data dan memilih data yang dapat digunakan dalam aplikasi permainan.

- Pembuatan Mock-Up: Pembuatan mock-up melibatkan pembuatan aset gambar dan penyusunan aset yang menjadi acuan dalam implementasi permainan. Mock-up juga berfungsi untuk memberikan ilustrasi bagaimana permainan tersebut dimainkan. Aset pada penelitian ini dibuat oleh vendor dengan diawasi oleh tim peneliti.

- Evaluasi: Evaluasi dilakukan oleh pakar perikanan budidaya untuk menguji faktor edukasi dari dokumen dan mock-up yang telah dihasilkan. Evaluasi dari pakar dapat dijadikan petunjuk dalam proses pembuatan dan pengembangan aplikasi permainan selanjutnya.

\section{HASIL DAN PEMBAHASAN}

\section{Inisiasi}

Berdasarkan diskusi dengan pakar, ikan budidaya yang dipilih dalam penelitian ini yaitu ikan nila, lele dumbo, mas majalaya, gurami, dan patin. Ikan-ikan tersebut dipilih berdasarkan jenis ikan budidaya paling populer menurut KKP (2015). Data pemeliharan untuk masingmasing ikan budidaya dapat dilihat pada Tabel 1. Selain data pada Tabel 1, sebagai bahan untuk pengembangan GDD, dilakukan pengumpulkan data karakteristik ikan dalam waktu budidaya yang meliputi waktu pada tiap tahap pemeliharaan (pendederan), frekuensi pemberian pakan, bobot pakan, kadar protein yang terkandung dalam pakan, serta sintasan (persentase jumlah ikan yang berhasil bertahan hidup pada saat panen). Data tersebut digunakan pada tahap berikutnya untuk memberikan mekanik permainan yang realistis. Kunjungan ke Kolam Percobaan BDP FPIK IPB dilakukan untuk mengetahui perikanan budidaya di dunia nyata. BDP FPIK IPB memiliki banyak kolam ikan dan peralatan untuk melakukan budidaya ikan. Studi lapangan di Kolam Percobaan BDP FPIK IPB dapat dilihat pada Gambar 2.

Dari hasil kunjungan lapangan ke kolam budidaya, diperoleh informasi mengenai jenis dan karakteristik kolam serta peralatan pendukung yang digunakan dalam proses budidaya kolam. Karakteristik dan deskripsi dari kedua objek tersebut tersebut dapat dilihat pada Tabel 2 dan Tabel 3. Sifat ini akan diadopsi ke dalam permainan dengan mempertimbangkan berbagai aspek seperti tingkat kesulitan permainan, tingkat kesamaan simulasi dengan dunia nyata, serta tingkat kesenangan saat bermain. Selain itu, proses umum perikanan budidaya juga diperoleh dari pakar dan dibuat dalam bentuk diagram seperti pada Gambar 3. Bagian atas gambar tersebut memperlihatkan proses budidaya dari tahap pemijahan, inkubasi, pendederan, dan panen. Bagian bawah memperlihatkan lokasi tempat proses tersebut dilaksanakan, yaitu pada kolam pemiijahan, kolam inkubasi, dan kolam pendederan.

\section{Pembuatan Dokumen Desain Permainan}

Pembuatan GDD juga melalui proses perancangan unsur edukatif(Vicuna 2017) dan nonedukatif seperti gambaran luas aplikasi permainan, influences, deskripsi aplikasi permainan, mekanik permainan, dan cara bermain.

Tabel 1 Data pemeliharaan ikan budidaya

\begin{tabular}{|c|c|c|c|c|c|}
\hline Jenis Ikan & Wadah & $\begin{array}{l}\text { Waktu budidaya } \\
\text { (bulan) }\end{array}$ & $\begin{array}{l}\text { Padat tebar } \\
\left(\text { ekor } / \mathrm{m}^{2}\right)\end{array}$ & $\begin{array}{c}\text { Sintasan } \\
(\%)\end{array}$ & Dokumen Terkait \\
\hline Nila & Tanah atau tembok & $4-5$ & $5-7$ & 75 & $\begin{array}{l}\text { SNI 7550:2009, SNI } \\
6140: 2009\end{array}$ \\
\hline Lele Dumbo & Tanah atau tembok & $6-7$ & $20-35$ & 80 & $\begin{array}{l}\text { SNI } 01-6484.4-2000 \text {, } \\
\text { SNI 6484.3:2014 }\end{array}$ \\
\hline $\begin{array}{l}\text { Mas } \\
\text { Majalaya }\end{array}$ & Tanah atau tembok & $3-4$ & 10 & $75-80$ & $\begin{array}{l}\text { SNI } 01-6131-1999 \text {, } \\
\text { SNI } 01-6132-1999 \text {, } \\
\text { SNI } 01-6133-1999\end{array}$ \\
\hline Gurami & Tanah, tembok, plastik & $4-5$ & $5-7$ & $85-95$ & $\begin{array}{l}\text { SNI } 01 \text { - 6485.3-2000, } \\
\text { SNI } 01-7241-2006\end{array}$ \\
\hline Patin & Tanah atau tembok & $6-10$ & $5-7$ & 90 & SNI 7551:2009 \\
\hline
\end{tabular}




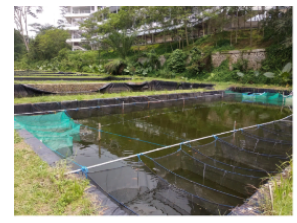

Kolam tanah

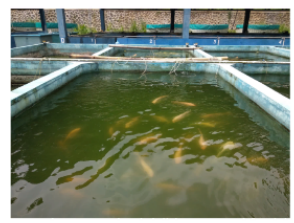

Kolam tembok

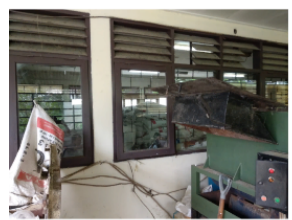

Ruang pengolahan

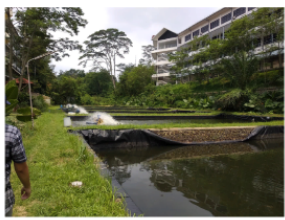

Kolam tanah

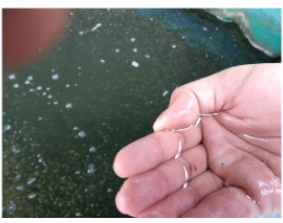

Larva ikan

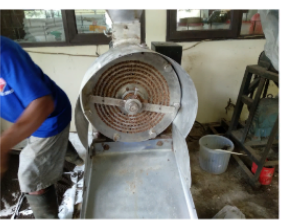

Pengolah pakan

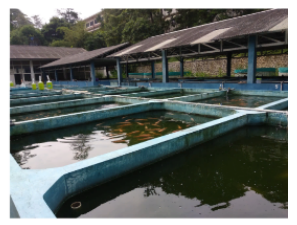

Kolam tembok

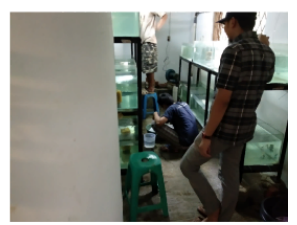

Ruang penelitian

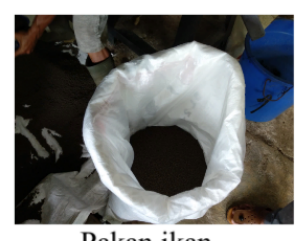

Pakan ikan

Gambar 2 Dokumentasi studi lapangan di kolam budidaya.

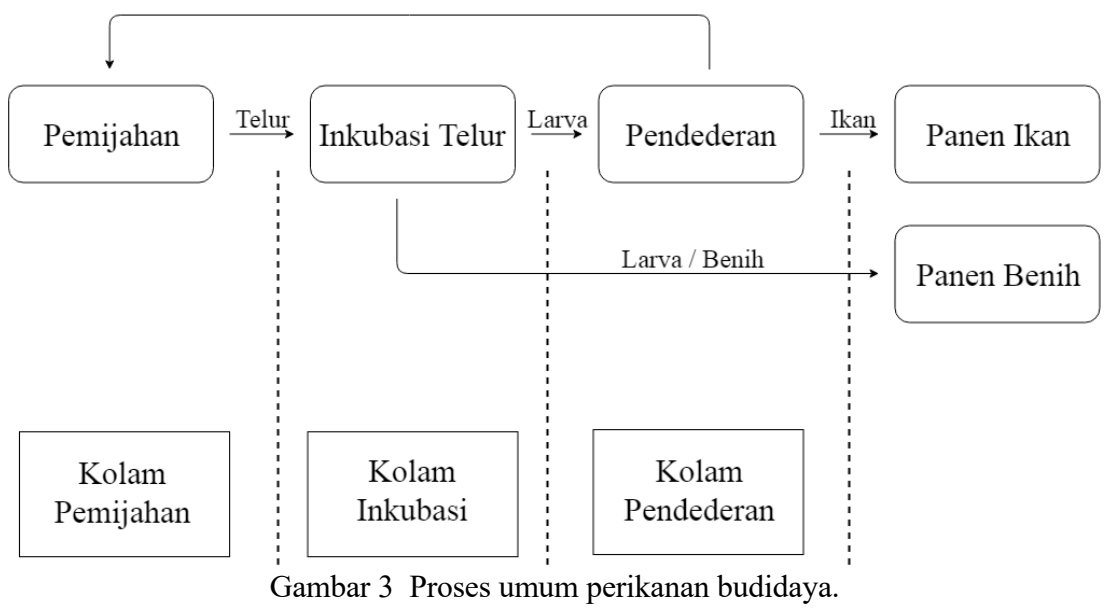

Tabel 2 Jenis kolam dan karakteristik kolam

\begin{tabular}{|c|c|c|}
\hline Jenis Kolam & Kelebihan & Kekurangan \\
\hline Tanah & $\begin{array}{l}\text { - } \text { Keadaan lebih alami } \\
\text { - } \text { Biaya lebih murah } \\
\text { - } \text { Banyak unsur hara } \\
\text { - } \text { Kebersihan terjaga secara alami } \\
\text { - Banyak pakan alami ikan }\end{array}$ & $\begin{array}{ll}\text { - } & \text { Rentan bocor } \\
\text { - } & \text { Sulit mengatur kualitas air } \\
\text { - } & \text { Sulit mengontrol suhu } \\
\text { - } & \text { Mudah kehilangan air } \\
\text { - } & \text { Sulit mengontrol predator }\end{array}$ \\
\hline Semi-tanah & $\begin{array}{l}\text { - Lebih murah dari kolam tembok } \\
\text { - Unsur hara alami dari tanah } \\
\text { - Kebersihan terjaga secara alami } \\
\text { - } \quad \text { Cukup banyak sumber pakan alami }\end{array}$ & $\begin{array}{l}\text { - } \quad \text { Cukup sulit mengatur kualitas air } \\
\text { - } \quad \text { Cukup sulit mengontrol suhu } \\
\text { - } \quad \text { Masih cukup rentan bocor } \\
\text { - } \quad \text { tanawatan lebih sulit dibanding kolam }\end{array}$ \\
\hline Tembok & $\begin{array}{ll}\text { - } & \text { Tahan bocor } \\
\text { - } & \text { Mudah mengatur kualitas air } \\
\text { - } & \text { Relatif mudah mengontrol predator } \\
\text { - } & \text { Lebih mudah mengontrol suhu } \\
\end{array}$ & $\begin{array}{l}\text { - } \quad \text { Sedikit pakan alami ikan } \\
\text { - } \quad \text { Biaya relatif mahal } \\
\text { - } \quad \text { Perawatan kebersihan lebih sulit } \\
\text { - Tidak ada unsur hara alami } \\
\end{array}$ \\
\hline
\end{tabular}


Tabel 3 Barang-barang dalam perikanan budidaya

\begin{tabular}{ll}
\hline Barang & Deskripsi \\
\hline Pakan ikan & Makanan utama ikan yang mempengaruhi pertumbuhan ikan. \\
Obat & Menyembuhkan ikan dari penyakit yang disebabkan oleh bakteri, virus, atau patogen lain. \\
Kapur & Mengurangi keasaman air yang dapat meningkat oleh hasil ekskresi ikan. Ikan memiliki \\
& batas toleransi keasaman air agar dapat hidup dan berkembang dengan baik. \\
Pupuk & Memberi unsur hara agar ikan bertumbuh lebih cepat. \\
\hline
\end{tabular}

\section{Gambaran Luas Aplikasi Permainan}

Bagian ini terdiri atas tema, target pemain, dan rancangan monetisasi. Tema yang dipilih dalam rancangan ini yaitu "Aquaculture for a better future" untuk membantu memperkenalkan perikanan budidaya. Aplikasi permainan yang dirancang memiliki gaya kombinasi dari gaya kasual, edukatif, dan simulasi. Target pemain yang dipilih yaitu berusia di atas 13 tahun karena permainan mengandung konten edukatif dan bahasa utama yang digunakan adalah bahasa Inggris. Selain itu, dalam rancangan juga terdapat model monetisasi pembelian dalam aplikasi (in-app purchase) sehingga perlu perancangan khusus jika target pemain berusia di bawah 13 tahun sesuai dengan Children's Online Privacy Protection Rule (COPPA) oleh FTC (2013).

GDD memuat skema monetisasi untuk menjamin keberlangsungan permainan di pasar. Rancangan monetisasi mengikuti model monetisasi yang lazim digunakan pada aplikasi permainan sejenis. Pemain akan menggunakan waktu mereka untuk mengembangkan bisnis budidaya ikan, membudidayakan ikan, dan menjual ikan untuk mendapatkan uang virtual dalam aplikasi permainan yang dapat digunakan untuk membeli barang, alat, ataupun ikan baru. Uang virtual tersebut dapat dibeli melalui pembelian dalam aplikasi untuk mempercepat proses tersebut. Sistem monetisasi ini didasarkan pada ikatan emosi dengan usaha budidayanya di dalam permainan sehingga pemain merasakan dorongan untuk mengembangkan usaha tersebut. Dengan adanya ikatan emosi tersebut, pemain akan lebih bersedia untuk memberikan dukungan pada pengembang baik dengan cara melihat iklan yang diberikan dengan imbalan bonus bagi pemain maupun pembelian uang virtual melalui pembelian dalam aplikasi (Chartboost 2013). Beberapa pengait emosi yang digunakan adalah penanda waktu (timer), peluang mendapatkan suatu barang, serta aksi instan.

Penanda waktu terpasang untuk menandakan durasi pemain harus menunggu suatu aksi selesai, misalnya proses peningkatan kualitas kolam dari kolam tanah ke semi-tanah. Durasi tersebut dapat dihilangkan dengan melihatkan iklan yang memberikan pemasukan bagi pengembang. Beberapa barang diberikan secara gratis dalam jumlah kecil, namun hanya bisa dibeli dalam jumlah besar melalui transaksi dalam aplikasi. Barang ini memberikan efek mengurangi durasi atau hal-hal lain yang menguntungkan pemain. Walaupun demikian, tanpa adanya barang ini sekalipun, pemain tetap dapat menyelesaikan permainan meskipun memerlukan waktu yang lebih lama.

\section{Karya yang Berpengaruh pada Rancangan}

Terdapat empat karya yang berpengaruh besar pada rancangan permainan ini, yaitu proses budidaya di dunia nyata, permainan Harvest Moon, permainan Recettear, dan permainan karya studio Kairosoft. Keempat hal tersebut memberikan pengaruh dalam mekanik gameplay dan elemen lain dalam aplikasi permainan. Ringkasan dari pengaruh keempat hal tersebut dapat dilihat pada Tabel 4. Hal-hal tersebut diambil agar pemain dapat segera merasa familiar dengan konsep permainan yang diberikan dan dapat beradaptasi secepat mungkin di dalam permainan.

\section{Deskripsi Permainan}

Deskripsi permainan menjelaskan tentang aplikasi permainan yang akan dibuat, pemain yang dituju, dan tujuan permainan ini dibuat. Permainan ini dirancang untuk memperkenalkan perikanan budidaya sambil bermain aplikasi permainan. Pemain yang dituju adalah pemain aplikasi permainan kasual yang bermain untuk mengisi waktu luang. Permainan ini 
Tabel 4 Ringkasan pengaruh dari empat karya yang menjadi referensi rancangan permainan

\begin{tabular}{ll}
\hline Barang & Deskripsi \\
\hline Perikanan & Proses mekanik gameplay pada aplikasi permainan berasal dari perikanan budidaya kehidupan \\
Kehidupan & nyata. Pemain melakukan budidaya perikanan dalam aplikasi permainan dari telur ikan hingga \\
Nyata & ikan dewasa dan dapat dijual untuk mendapatkan keuntungan. Perikanan budidaya dunia nyata \\
& juga digunakan sebagai referensi konten edukatif dalam aplikasi permainan berdasarkan data \\
Harvest Moon & dan referensi yang telah dikumpulkan. \\
& Referensi yang diambil dari aplikasi permainan Harvest Moon yaitu simulasi pertanian dunia \\
& nyata pada Harvest Moon. Simulasi dunia nyata pada Harvest Moon yang digunakan dalam \\
& aplikasi permainan ini yaitu sistem pergantian cuaca terhadap waktu dan efek pergantian cuaca \\
& tersebut dalam menjalankan bisnis dalam aplikasi permainan. \\
& Referensi yang diambil dari aplikasi permainan Recettear yaitu popularitas dan perubahan \\
& harga dari suatu barang. Referensi tersebut digunakan dalam mekanik gameplay, yaitu \\
& permintaan musiman. Pada aplikasi permainan yang dirancang, harga jual jenis ikan tertentu \\
& dapat berubah menjadi lebih mahal atau murah tergantung permintaan, seperti harga barang \\
& pada Recettear. \\
& Kairosoft adalah salah satu studio aplikasi permainan di Jepang yang banyak membuat aplikasi \\
& permainan simulasi. Referensi yang diambil dari aplikasi permainan karya Kairosoft adalah \\
& penggunaan timer pada elemen dalam aplikasi permainan yang digunakan sebagai waktu \\
& tunggu yang diperlukan untuk membangun fasilitas. Pada aplikasi permainan ini, timer \\
Kairosoft & digunakan pada beberapa elemen dalam aplikasi permainan, yaitu waktu pembangunan \\
& fasilitas, waktu pertumbuhan ikan, dan waktu penelitian dengan laboratorium. Selain \\
& penggunaan timer, aplikasi permainan ini menggunakan proyeksi isometrik seperti pada \\
& aplikasi permainan karya Kairosoft. \\
\hline
\end{tabular}

menggunakan pengaturan kamera ortografis dengan proyeksi isometrik, yang merupakan gaya yang lazim digunakan pada permainan dengan gaya simulasi.

Pada mulanya, pemain diberikan sebuah kolam untuk melakukan budidaya ikan. Pemain dapat membeli kolam baru untuk mengembangkan bisnis. Ikan yang dimiliki harus diberi makan secara teratur untuk dapat bertumbuh dengan baik. Pemain juga harus memperhatikan kondisi kolam agar tidak kotor ataupun bocor. Selain itu, pemain juga harus memperhatikan pengeluaran dan pemasukan uang untuk menjalankan bisnis perikanan budidaya. Pengeluaran uang terjadi ketika pemain membeli ikan, barang, alat, ataupun membangun fasilitas baru. Sedangkan pemasukan uang dapat diperoleh pemain dengan menjual ikan atau telur ikan.

\section{Mekanik Permainan dari Sisi Waktu}

Ikan yang dibudidaya akan tumbuh seiring berjalannya waktu. Sistem waktu yang digunakan adalah hasil konversi dari waktu pada kehidupan nyata ke dalam waktu aplikasi permainan. Waktu dapat dipercepat menggunakan barang khusus. Perhitungan waktu dalam aplikasi permainan yaitu satu bulan dalam aplikasi permainan setara dengan dua hari di dunia nyata, sehingga satu hari dalam aplikasi permainan setara dengan bermain selama 1.6 jam. Konversi waktu dilakukan seperti pada aplikasi permainan Harvest Moon. Namun pada aplikasi permainan ini, waktu dalam aplikasi permainan tetap berjalan meskipun pemain keluar dari aplikasi permainan. Selain itu, pembangunan fasilitas, pemberian pakan ikan, dan perawatan fasilitas menggunakan timer, seperti pada aplikasi permainan karya Kairosoft, sehingga pemain harus kembali bermain untuk memberi pakan ikan dan merawat fasilitas. Jika pemain tidak kembali bermain untuk memberi pakan atau merawat fasilitas, ikan yang dibudidaya dapat mati karena kelaparan dan fasilitas dapat menjadi rusak.

\section{Mekanik Permainan dari Sisi Ikan}

Ikan dalam aplikasi permainan memiliki parameter perawatan seperti pada perikanan budidaya kehidupan nyata. Parameter tersebut terdiri atas pertumbuhan ikan, harga jual, harga beli, kesehatan, pakan, umur, dan kondisi lingkungan yang cocok dengan ikan tersebut. Pemain harus memperhatikan parameter tersebut agar ikan yang dibudidaya bertumbuh dengan baik dan menghasilkan keuntungan yang maksimal. Proses budidaya ikan dibuat berdasarkan keadaan di dunia nyata (Gambar 3). Pada aplikasi permainan terdapat permintaan musiman 
seperti pada Recettear. Permintaan musiman adalah suatu kejadian dalam aplikasi permainan yang menyebabkan popularitas suatu jenis ikan berubah sehingga harga jual ikan tersebut berubah. Harga jual ikan dapat bertambah ataupun berkurang. Pemain dapat memanfaatkan event ini untuk mendapatkan keuntungan lebih besar dengan menjual ikan yang sedang tinggi permintaan. Pemain juga harus menghindari menjual ikan yang sedang memiliki harga rendah untuk menghindari kerugian.

\section{Mekanik Permainan dari Sisi Kolam Ikan}

Karakteristik kolam dalam aplikasi permainan ditunjukkan melalui parameter kolam. Parameter tersebut yaitu: daya tahan kolam, harga untuk membangun kolam, oksigen terlarut yang terkandung di dalam kolam, temperatur kolam, kadar amonia dalam kolam, kadar unsur hara, dan tipe dari kolam. Pemain harus merawat kolam ikan dan memperhatikan parameter kolam agar ikan dapat bertumbuh dengan baik. Jika pemain tidak merawat kolam dengan baik, maka ikan yang terdapat pada kolam tersebut dapat mengalami kematian massal.

Keunggulan dan kekurangan antarkolam harus seimbang agar tidak ada jenis kolam yang memiliki keunggulan yang tidak seimbang dibandingkan dengan jenis kolam lain. Dengan demikian, ketiga jenis kolam dapat menjadi pilihan yang dapat diambil oleh pemain sehingga pemain dapat menentukan strategi dalam mengolah bisnis perikanan budidaya dalam aplikasi permainan. Karakteristik kolam yang dapat mempengaruhi lingkungan hidup ikan yaitu daya tahan, jumlah pakan alami, kandungan unsur hara, dan kapasitas kolam yang akan bergantung pada level dari kolam tersebut. Untuk memudahkan pengembang yang akan mengimplementasikan karakter tersebut (King 2015), setiap karakteristik tersebut disajikan dalam bentuk grafik yang dapat dilihat pada Gambar 4a hingga Gambar 4d. Grafik tersebut diadaptasi berdasarkan hasil studi pada tahap inisiasi dan diverifikasi kepada pakar perikanan.

\section{Mekanik Permainan dari Sisi Barang dan Fasilitas Pendukung}

Pemain juga dapat menggunakan barang-barang perikanan budidaya dalam merawat ikan. Barang-barang dalam aplikasi permainan berasal dari perikanan budidaya dunia nyata, yaitu auto-feeder (memberi pakan ikan secara otomatis), aerator (meningkatkan kadar oksigen terlarut), pengatur kualitas air, pembuat pakan ikan, tempat pengolahan ikan, laboratorium, serta sistem pengolahan air secara otomatis (recirculating aquaculture system). Fasilitas ini dapat diakses oleh pemain secara bertahap seiring dengan perkembangan usahanya.

\section{Mekanik Permainan dari Sisi Cuaca}

Seperti pada aplikasi permainan Harvest Moon, cuaca pada aplikasi permainan ini dapat berubah. Ada dua tipe cuaca, yaitu cerah dan hujan. Kondisi ikan dapat dipengaruhi oleh kondisi cuaca. Cuaca tidak berpengaruh terhadap pertumbuhan ikan ketika cuaca normal, yaitu tidak cerah ataupun hujan yang berkepanjangan. Cuaca cerah yang berkepanjangan dapat menurunkan kadar oksigen dalam kolam ikan. Hujan yang berkepanjangan dapat mengurangi nafsu makan ikan sehingga memperlambat pertumbuhan ikan dan juga dapat memicu wabah penyakit. Cuaca didasarkan pada kondisi di Indonesia, terutama di wilayah Bogor yang diperoleh dari Weatherbase (2018).

\section{Mekanik Permainan dari Sisi Fitur Lainnya}

Fitur atau konten tidak semua dapat diakses pemain sejak awal untuk menciptakan alur pengalaman yang mulus, seperti pada Flow Theory (Vicuna 2017), sehingga pemain tidak kesulitan dalam memainkan aplikasi permainan. Pembukaan fitur atau konten dilakukan berdasarkan level pemain dan waktu dalam permainan. Daftar pembukaan fitur berdasarkan level dan waktu dapat dilihat pada Tabel 5. 

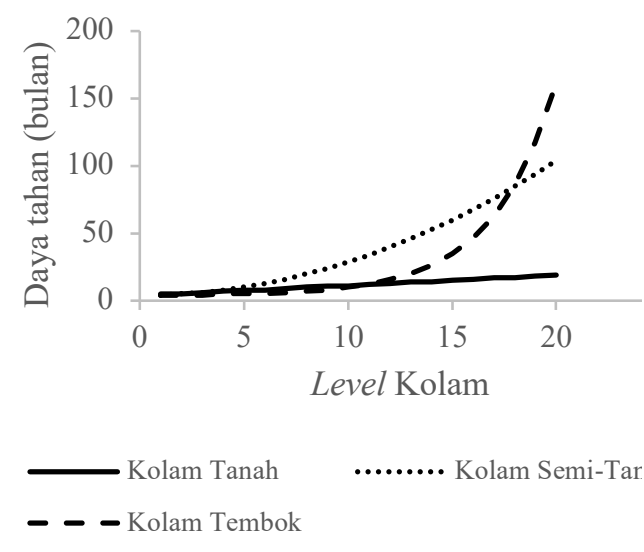

(a) Daya tahan kolam.

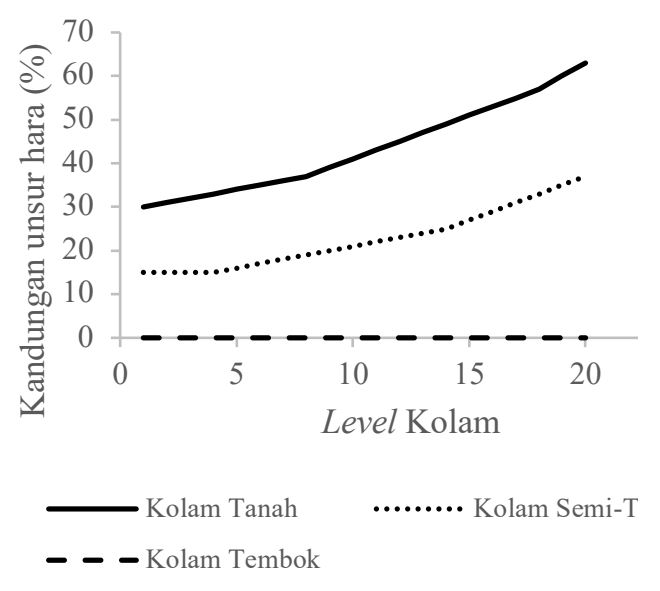

(c) Unsur hara kolam.
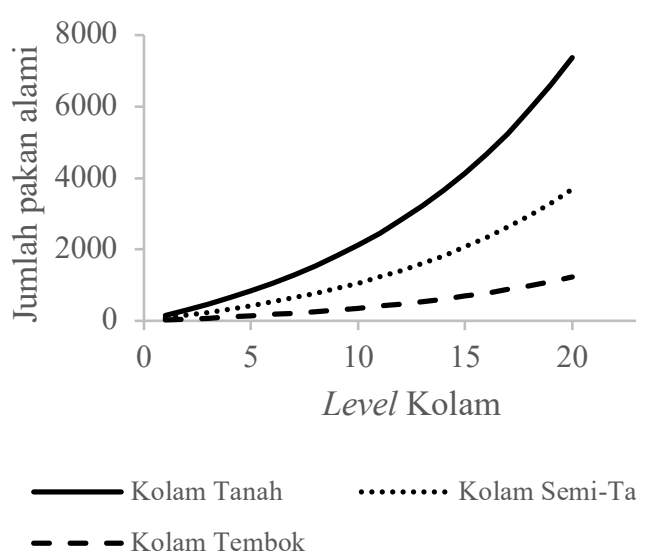

(b) Jumlah pakan alami kolam.

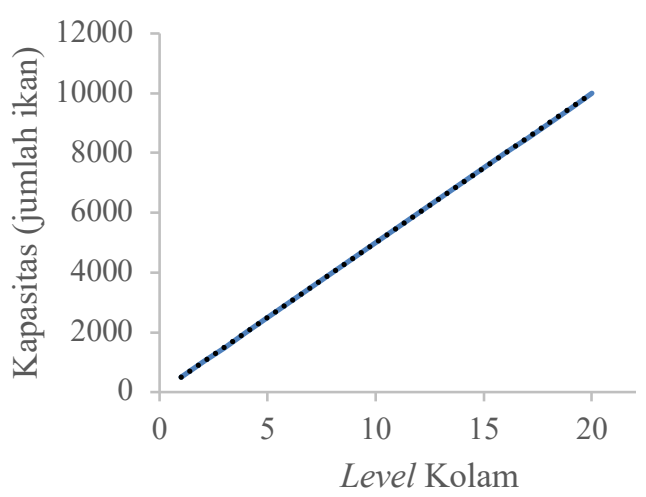

(d) Kapasitas kolam.

Gambar 4 Grafik perbandingan karakteristik setiap jenis kolam pada permainan.

Tabel 5 Daftar fitur berdasarkan level pemain

\begin{tabular}{|c|c|c|c|c|c|}
\hline \multirow[t]{2}{*}{$\mathrm{vl}$} & \multirow[t]{2}{*}{ Konten } & \multicolumn{2}{|r|}{ Konten } & \multicolumn{2}{|r|}{ Konten } \\
\hline & & vl & & $\mathrm{vl}$ & \\
\hline 1 & Kolam Tanah & 12 & Aerator & 26 & Perluasan Lahan \\
\hline & Pakan Ikan & 13 & Ikan Lele & 27 & Ikan Patin \\
\hline & Obat & 16 & $\begin{array}{l}\text { Kolam } \\
\text { Tembok }\end{array}$ & 30 & Riset Pemberi Pakan Otomatis \\
\hline & Ikan Nila & 20 & Laboratorium & 35 & Riset Pengatur Kualitas Air \\
\hline 5 & Predator & & Riset Pupuk & 40 & Rumah Produksi \\
\hline 7 & Ikan Mas & 21 & Ikan Gurami & 45 & Riset Sistem Pengolahan Air Otomatis \\
\hline 12 & Kolam Semi-Tanah & 22 & Riset Kapur & & \\
\hline
\end{tabular}

\section{Mock-Up Permainan}

Pada tahap ini, dibuat gambaran kasar dari aplikasi yang akan dikembangkan. Sebagian aset dan gambaran tersebut dapat dilihat pada Gambar 5 .

\section{Evaluasi oleh pakar}

Evaluasi rancangan aplikasi permainan dilakukan oleh pakar budidaya perairan dengan melakukan validasi unsur edukatif yang terdapat pada rancangan aplikasi permainan hasil penelitian ini. Selain melakukan validasi, pakar juga memberikan masukan agar aplikasi permainan yang dirancang dapat lebih baik. Menurut pakar, rancangan dan mock-up hasil penelitian ini telah berhasil menghasilkan rancangan yang edukatif dan sangat menarik. Aplikasi permainan yang dirancang dinilai mampu digunakan untuk memperkenalkan 

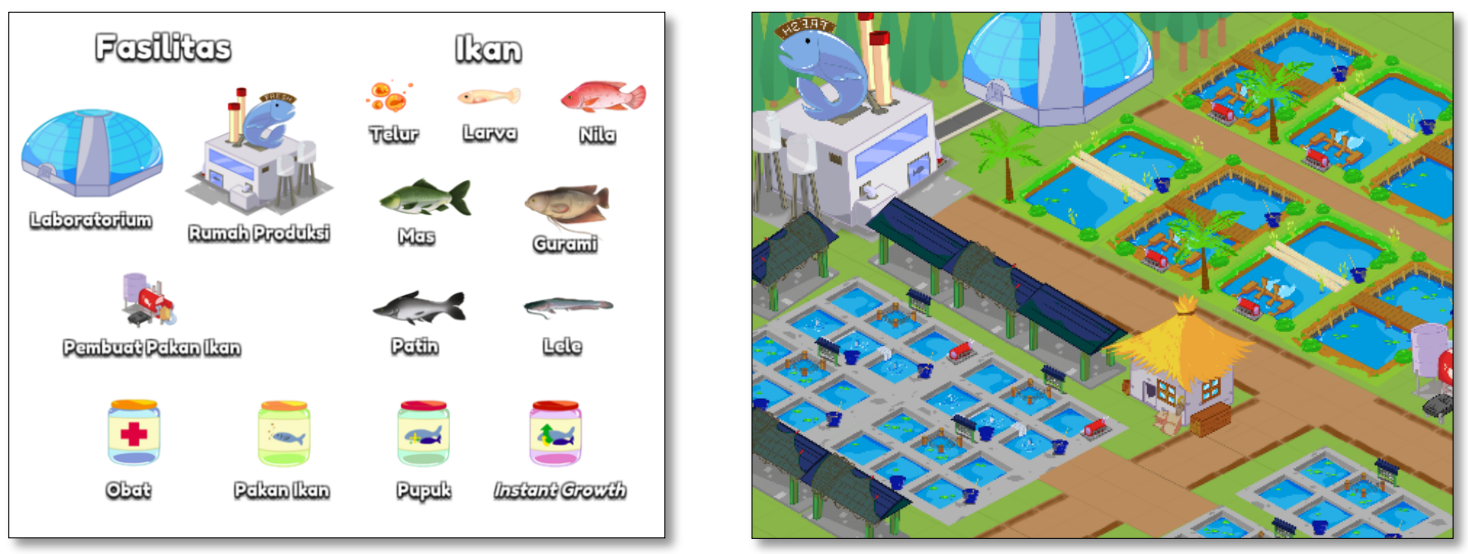

Gambar 5 Mock-up dari permainan yang akan dikembangkan.

perikanan budidaya kepada pemain. Beberapa masukan dan perbaikan terhadap dokumen yang dihasilkan adalah:

- Hujan berkepanjangan dalam dunia nyata dapat menyebabkan wabah penyakit karena nafsu makan ikan berkurang sehingga daya tahan ikan terhadap penyakit juga menurun,

- Pemberian pakan ikan berlebih dapat menyebabkan kolam ikan menjadi kotor karena banyak pakan yang tidak dimakan oleh ikan,

- Jamu dapat digunakan sebagai pengganti obat, dan batang pisang dapat digunakan sebagai pengganti kalsium,

- Pupuk dapat digantikan dengan probiotik untuk meningkatkan pertumbuhan,

- Pada dunia nyata, ukuran ikan saat panen dapat beragam,

- Pada dunia nyata, kolam tanah memerlukan persiapan sebelum dapat digunakan.

Beberapa masukan dari pakar dapat segera dipenuhi pada penelitian ini. Namun, ada beberapa masukan dari pakar yang memerlukan penelitian lebih lanjut sebelum dapat dimasukkan ke dalam rancangan aplikasi permainan. Penggunaan jamu, batang pisang, dan probiotik memerlukan penelitian lebih lanjut untuk mengetahui jenis dan fungsi masing-masing barang. Penerapan ukuran ikan beragam dalam aplikasi permainan juga perlu diteliti dan dipertimbangkan lebih lanjut agar mekanik permainan tetap menyenangkan. Penerapan fitur persiapan kolam tanah sebelum digunakan juga memerlukan peneltian lebih lanjut untuk mengetahui tindakan yang perlu dilakukan dan mekanik permainan seperti apa yang akan diterapkan dalam aplikasi permainan.

\section{Penelitian Selanjutnya}

Pada penelitian ini, game balancing yang dilakukan untuk memodelkan perikanan budidaya di kehidupan nyata ke dalam aplikasi permainan. Pada tahap penelitian selanjutnya akan dilaksanakan proses implementasi permainan dalam bentuk program, pengujian dan penyeimbangan parameter yang telah disusun dalam penelitian ini, serta pengujian pengalaman pengguna dalam bermasin seperti yang dilakukan oleh Asfarian et al. (2019).

\section{SIMPULAN}

Penelitian ini telah berhasil merancang aplikasi permainan edukatif yang menarik tentang perikanan budidaya. Penelitian ini dilakukan dengan GDLC pada tahap inisiasi dan praproduksi. Rancangan hasil penelitian ini dapat digunakan untuk pengembangan tahap selanjutnya untuk menciptakan aplikasi permainan edukatif tentang perikanan budidaya. Penelitian ini hanya berfokus pada tahap inisiasi dan pra-produksi dari GDLC. Pada tahap pengembangan selanjutnya, game balancing perlu dilakukan dan diuji lebih lanjut karena game balance hasil penelitian ini hanya game balancing sederhana. Selain game balancing, penelitian 
lebih lanjut diperlukan untuk menambah atau mengubah mekanik gameplay agar lebih sesuai dengan perikanan budidaya kehidupan nyata, seperti penggunaan jamu sebagai obat, batang pisang sebagai pengganti kalsium, penggunaan probiotik dalam perikanan budidaya, dan persiapan yang diperlukan sebelum kolam dapat digunakan. Menurut pakar, aplikasi permainan yang dirancang dinilai mampu digunakan untuk memperkenalkan perikanan budidaya kepada pemain.

\section{DAFTAR PUSTAKA}

Andreu MAA, García CM. 2011. Perceptions of gaming as experiential learning by engineering students. International Journal of Engineering Education. 27 (4): 795-804.

Asfarian A, Ramadhan W, Putra WA, Raharjanto GM, Frisky R. 2019. Creating a circular tower defense game: development and game experience measurement of Orbital Defense X. Kinetik: Game Technology, Information System, Computer Network, Computing, Electronics, and Control. 4 (3): 249-58.

Clearwater D. 2011. What defines video game genre? Thinking about genre study after the great divide. Loading.... The Journal of the Canadian Game Studies Association. 5 (8): 29-49.

Haworth R, Sedig K. 2011. The importance of design for educational games. Education in a technological world. 518-22.

King A. 2015. Numbers Getting Bigger: The Design and Math of Incremental Games. [Internet]. [diakses 2018 Agu 25]; gamedevelopment.tutsplus.com /articles/numbersgetting-bigger-the-design-and-math-of-incremental-games--cms-24023.

Phillips M, Henriksson P, Tran N, Chan C, Mohan C, Rodriguez U, Suri S, Hall S, Koeshendrajana S. 2016. Menjelajahi Masa Depan Perikanan Budidaya Indonesia. [Internet]. [diunduh 2018 Feb 26]; pubs.iclarm.net/resource_centre/2016-02.pdf.

Pho A, Dinscore A. 2015. Game-Based Learning. Instructional Technologies Committee. Tips and Trends [Internet]. [diunduh 2017 Nov 11]; acrl.ala.org/IS/wpcontent/uploads/2014/05/spring2015.pdf.

Ramadan R, Widyani Y. 2013. Game development life cycle guidelines. Di dalam 2013 International Conference on Advanced Computer Science and Information Systems (ICACSIS) 2013 Sep 28 (pp. 95-100). IEEE.

Stanley B. 2014. Game Design Document Template. [Internet]. [diakses 2018 Jan 1]; docs.google.com/document/d/1-I08qX76DgSFyN1ByIGtPuqXh7bVKra HcNIA25tpAzE.

Vicuna L. 2017. Educational Games Design: Creating an Effective and Engaging Learning Experience [skripsi]. Helsinki (FI): Helsinki Metropolia University of Applied Sciences.

[Chartboost] Chartboost. 2013. Emotional Monetization-Revenue Through Emotion. [Internet]. [diakses 2018 Apr 1]; chartboost.com/blog/2013/11/emotional-monetization-how-tomonetize-with-great-design/.

[FTC] Federal Trade Commission. 2013. Children's Online Privacy Protection Act. [Internet]. [diakses 2018 Apr 6]; ftc.gov/system/files/2012-31341.pdf.

[KKP] Kementerian Kelautan dan Perikanan. 2015. Potensi Usaha Budidaya Ikan Air Tawar. [Internet]. [diakses 2018 Mar 1]; news.kkp.go.id/index.php/potensi-usaha-budidayaikan-air-tawar.

[SetKabRI] Sekretariat Kabinet Republik Indonesia. 2016. Potensi Besar Perikanan Tangkap Indonesia. [Internet]. [diakses 2018 Feb 26]; setkab.go.id/potensi-besar-perikanantangkap-indonesia/.

[Weatherbase] Weatherbase. 2018. Bogor, Indonesia Travel Weather Averages (Weatherbase). [Internet]. [diakses $2018 \mathrm{Agu} 9$ ]; weatherbase.com/weather/weather.php3?s=602269\& cityname $=$ Bogor $\% 2 \mathrm{C}+$ West $+\mathrm{Java} \% 2 \mathrm{C}+$ Indonesia. 